\title{
KESESUAIAN LOKASI DAN TANGGAPAN MASYARAKAT UNTUK TEMPAT PEMROSESAN AKHIR (TPA) SAMPAH DI KOTA KOTAMOBAGU
}

\author{
Hariyono Gumalangit \\ Zetly E. Tamod \\ Bobby Polii
}

\begin{abstract}
This study aims to analyze the appropriate location and community responses for waste landfill sites and to determine the factors that limit the level of land suitability for waste landfill in Kota Kotamobagu. The study was conducted in the designated area for the development of the Kotamobagu Municipal TPA location based on the RTRW document of Kota Kotamobagu for three months from February to March 2017. This research is observational. Research data is analyzed through quantitative descriptive method. The results showed that in the area designated as the location of TPA development in Kota Kotamobagu there is one candidate location that enter on the category of potential worthy in the area of West Mongkonai region based on the criteria of the feasibility of SNI 03-3241-1994. Communities around the landfill development/expansion sites for the TPA Poyowa Kecil tend to accept the presence of waste landfill and for the development site of West Mongkonai region waste landfill, people in the area tend to deny the existence of waste landfill sites. The limiting factor of land suitability for the landfill location in Kota Kotamobagu is classified into two namely the main limiting factor that is the social environment of the community in the form of rejection of the landfill location by the community around the landfill site and the physical limiting factor which consists of land permeability, rain intensity and agricultural area.
\end{abstract}

Keywords: land suitability, TPA, community response, Kota Kotamobagu, North Sulawesi Province

\begin{abstract}
ABSTRAK
Penelitian ini bertujuan untuk mengetahui lokasi yang layak dan tanggapan masyarakat untuk lokasi TPA sampah serta faktor-faktor yang menjadi pembatas tingkat kesesuaian lahan untuk TPA sampah di Kota Kotamobagu. Penelitian dilakukan di wilayah peruntukkan pengembangan lokasi TPA sampah Kota Kotamobagu berdasarkan dokumen RTRW Kota Kotamobagu selama tiga bulan sejak Februari sampai Maret 2017. Penelitian ini menggunakan data primer berupa wawancara dan bersifat observasional. Data penelitian dianalisis melalui metode deskriptif kuantitatif. Hasil penelitian menunjukkan bahwa di wilayah yang diperuntukkan sebagai lokasi pengembangan TPA di Kota Kotamobagu terdapat satu calon lokasi yang masuk pada kategori potensial layak yang berada di wilayah Kelurahan Mongkonai Barat berdasarkan penilaian kriteria kelayakan SNI 03-3241-1994. Masyarakat disekitar lokasi pengembangan/perluasan TPA sampah untuk TPA Poyowa Kecil cenderung menerima keberadaan TPA sampah dan sebaliknya untuk lokasi pengembangan TPA sampah Mongkonai Barat, masyarakat di wilayah tersebut cenderung menolak keberadaan lokasi TPA sampah. Faktor pembatas kesesuaian lahan untuk lokasi TPA di Kota Kotamobagu digolongkan menjadi dua yakni faktor pembatas utama yaitu lingkungan sosial masyarakat berupa penolakan terhadap lokasi TPA oleh masyarakat sekitar lokasi TPA sampah dan faktor pembatas fisik yang terdiri dari permeabilitas tanah, intensitas hujan dan kawasan pertanian.
\end{abstract}

Kata kunci: kesesuaian lahan, TPA, tanggapan masyarakat, Kota Kotamobagu, Provinsi Sulawesi Utara 


\section{PENDAHULUAN}

\section{Latar Belakang}

Sampah perkotaan akan tetap merupakan salah satu persoalan yang rumit yang dihadapi oleh pengelola kota dalam menyediakan sarana dan prasarana perkotaannya. Di samping persoalan bagaimana menyingkirkan sampah secara baik agar kota tersebut menjadi bersih dan tidak mengganggu lingkungan, namun pula bagaimana daerah yang kebetulan terpilih untuk lokasi tempat pembuangan akhir (TPA) tidak mengalami degradasi kualitas lingkungan akibat adanya TPA tersebut. Kegiatan umum yang dilaksanakan di sebuah TPA adalah pengurugan atau penimbunan sampah di lahan yang tersedia.

Proses penanganan sampah dimulai dari proses pengumpulan sampai dengan tempat pemrosesan akhir (TPA) secara umum memerlukan waktu yang berbeda sehingga diperlukan ruang untuk menampung sampah pada masing-masing proses tersebut. Guna memenuhi kebutuhan ruang dalam menetapkan lokasi TPA, seringkali dijumpai masalah-masalah besar yang perlu ditangani dengan seksama, seperti ketersediaan lahan, konflik sosial yang berujung pada penolakan keberadaan TPA sampah dan penurunan mutu lingkungan sehingga dalam pemilihan lokasi TPA perlu diarahkan sebagai alat mitigasi dampak.

Pembuangan akhir sampah (TPA) adalah tempat yang digunakan untuk menyimpan dan memusnahkan sampah dengan cara tertentu sehingga dampak negatif yang ditimbulkan kepada lingkungan dapat dihilangkan atau dikurangi.

Perkiraan-perkiraan dampak penting suatu lokasi TPA yang berpengaruh kepada masyarakat saat operasi maupun sesudah beroperasi harus sudah dapat diduga sebelumnya. Pendugaan dampak ini, diantaranya berkaitan dengan penerapan kriteria pemilihan lokasi TPA sampah. Mengamati beberapa fenomena kegagalan operasional TPA di Indonesia disebabkan oleh adanya respon masyarakat terhadap keberadaan TPA di lingkungannya, maka keberhasilan operasional suatu TPA sangat dipengaruhi oleh persepsi masyarakat di wilayah tersebut. Penetapan Lokasi TPA pada dasarnya juga untuk kepentingan masyarakat dalam upaya menangulangi sampah kota. Kesulitan mendapatkan lahan TPA sampah di perkotaan, terutama di kota metro/besar antara lain disebabkan munculnya penolakan dan atau keberatan masyarakat terhadap calon lokasi TPA sampah. Apabila hal ini tidak ditangani dengan tepat tepat akan menimbulkan konflik sosial.

Untuk dapat menentukan lokasi TPA yang memenuhi persyaratan tersebut diperlukan analisis berbagai parameter lingkungan dengan menggunakan berbagai metode dan teknik penilaian. Kriteria pemilihan lokasi TPA sampah di Indonesia telah diatur dalam Surat Keputusan Badan Standar Nasional Indonesia melalui SK SNI 033241-1994 tentang Tata Cara Pemilihan Lokasi Pembuangan Akhir (TPA) Sampah.

Berdasarkan Laporan Akhir Penyusunan Masterplan Pengelolaan Persampahan Kota Kotamobagu tahun 2014, salah satu permasalahan yang sedang dihadapi oleh pemerintah Kota kotamobagu terkait dengan pengelolaan sampah saat ini adalah lahan TPA eksisting di Poyowa kecil yang hampir penuh, sehingga pemerintah Kota Kotamobagu harus membangunan TPA baru yang membutuhkan lahan TPA yang baru.

\section{Rumusan Masalah}

Mengamati beberapa permasalahan pengelolaan sampah di Kota Kotamobagu seperti yang telah diuraikan di atas, maka dapat dirumuskan permasalahan pokok yakni, kebutuhan lahan TPA sampah baru yang memenuhi persyaratan dan kriteria kesesuaian lahan untuk lokasi TPA sehingga dapat meminimalisir terjadinya konflik sosial dan penurunan mutu lingkungan. Berdasarkan permasalahan pokok tersebut, dapat diidentifikasi beberapa hal mengemuka yang merupakan masalah-masalah mendasar yang melatarbelakangi perlu dilakukannya studi mengenai Kesesuaian Lokasi dan Tanggapan 
Masyarakat Untuk Tempat Pemrosesan Akhir (TPA) Sampah di Kota Kotamobagu di wilayah yang telah ditetapkan sebagai peruntukkan lokasi lokasi pengembangan TPA sampah di Kota Kotamobagu yakni: (1) lokasi mana yang layak untuk TPA sampah di Kota Kotamobagu; (2) bagaimana tanggapan masyarakat sekitar terhadap keberadaan lokasi TPA sampah tersebut; dan (3) faktorfaktor apa yang menjadi pembatas tingkat kesesuaian lahan untuk lokasi TPA sampah di Kota Kotamobagu.

\section{Tujuan Penelitian}

Tujuan penelitian ini adalah:

1. Menganalisa lokasi yang layak untuk tempat pemrosesan akhir (TPA) sampah di wilayah peruntukkan pengembangan lokasi TPA sampah di Kota Kotamobagu berdasarkan kriteria standar kelayakan yang berlaku untuk lokasi TPA sampah;

2. Menganalisa tanggapan masyarakat sekitar terhadap keberadaan lokasi TPA sampah di Kota Kotamobagu;

3. Untuk mengetahui faktor-faktor yang menjadi pembatas tingkat kesesuaian lahan untuk lokasi TPA sampah di Kota Kotamobagu.

\section{Manfaat Penelitian}

Manfaat yang diharapkan dalam penelitian ini antara lain:

1. Dapat dijadikan sebagai salah satu bahan pertimbangan bagi pemerintah kota Kotamobagu dalam perencanaan pembangunan TPA sampah.

2. Sebagai salah satu referensi bagi mahasiswa/peneliti yang akan melakukan studi lanjutan mengenai TPA di Kota Kotamobagu.

\section{METODOLOGI PENELITIAN}

\section{Waktu dan Tempat Penelitian}

Penelitian Penelitian ini dilakukan di wilayah yang ditetapkan sebagai peruntukan pengembangan lokasi Tempat Pemrosesan Akhir (TPA) sampah dalam sistem persampahan di Kota Kotamobagu yang dituangkan dalam dokumen rencana tata ruang Kota Kotamobagu 2014-2034 yakni, Desa Poyowa Kecil Kecamatan Kotamobagu Selatan dan Kelurahan Mongkonai Barat Kecamatan Kotamobagu Barat Kota Kotamobagu.

Wilayah kajian meliputi daerah yang batas sosial dan batas administrasi. Gambaran lokasi penelitian tersaji pada Gambar 8.

Penelitian ini dilaksanakan pada bulan Januari sampai dengan bulan Maret 2017. Analisis tanah dilaksanakan di Laboratorium Fisika Jurusan Tanah Fakultas Pertanian Universitas Sam Ratulangi Manado

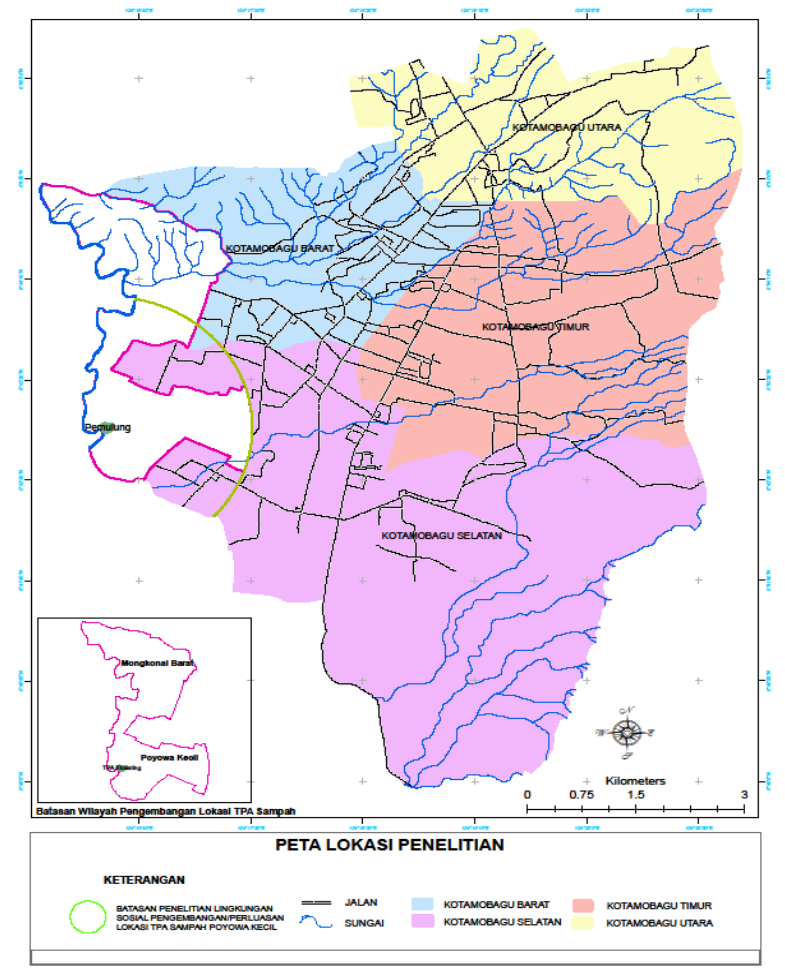

Gambar 1. Peta Lokasi Penelitian

\section{Bahan dan Alat Penelitian}

Bahan utama yang dipergunakan dalam penelitian ini yaitu lahan di wilayah yang ditetapkan sebagai peruntukan pengembangan lokasi Tempat Pemrosesan Akhir (TPA) sampah di Kota Kotamobagu. Sedangkan bahan lainnya antara lain yakni, peta dasar Kota Kotamobagu skala 1:25.000 berupa peta administrasi dan peta perairan (sumber pembuatan peta administrasi dan sungai) dan peta tematik Kota Kotamobagu skala 1:25.000 berupa peta kemiringan lahan, 
penggunaan lahan, peta morfologi, peta geologi (sumber pembuatan peta lereng, peta penggunaan lahan, peta bentuk lahan, geologi dan zona sesar aktif), peta pola ruang Kota Kotamobagu (sumber peta kawasan lindung), dokumen tata ruang Kota Kotamobagu (sumber rencana peruntukan lahan), dokumen rencana pengelolaan persampahan Kota Kotamobagu dan SNI 03-3241-1994 (sumber pengharkatan kelayakan dan kesesuaian lahan untuk lokasi TPA sampah), sampel tanah serta bahan lainnya yang diperlukan dalam pengujian di laboratorium.

\section{Metode Pengumpulan Data}

Data yang digunakan dalam penelitian ini adalah data melalui analisis tanah yang dilaksanakan di Laboratorium Fisika Jurusan Tanah Fakultas Pertanian Universitas Sam Ratulangi Manado.

Bahan yang digunakan dalam penelitian ini, antara lain lahan peruntukkan lokasi pengembangan TPA, peta dasar Kota Kotamobagu skala 1:25.000 berupa peta administrasi dan peta perairan (sumber pembuatan peta administrasi dan sungai) dan peta tematik Kota Kotamobagu skala 1:25.000 berupa peta kemiringan lahan, penggunaan lahan, peta morfologi, peta geologi (sumber pembuatan peta lereng, peta penggunaan lahan, peta bentuk lahan, geologi dan zona sesar aktif), peta pola ruang Kota Kotamobagu (sumber peta kawasan lindung), dokumen tata ruang Kota Kotamobagu (sumber rencana peruntukan lahan) dan SNI 03-3241-1994 (sumber pengharkatan kelayakan dan kesesuaian lahan untuk lokasi TPA sampah), sampel tanah serta bahan lainnya yang diperlukan dalam pengujian di laboratorium.

Alat yang digunakan yaitu, software ArcGIS 10.1, GPS (Global Positioning System), Klinometer untuk mengukur kelerengan, kamera, meteran untuk mengukur tinggi muka air tanah dan alat untuk pengambilan sampel tanah, serta angket dalam bentuk kuesioner yang dilengkapi dengan alat tulis menulis.

\section{Metode Pengambilan Sampel}

Penelitian ini bersifat observasional sedangkan metode yang digunakan adalah metode deskriptif kuantitatif.

Pengumpulan data biofisik dilakukan dengan teknik survey melalui pengamatan dan pengukuran karakteristik lahan di tingkat lapang dengan menentukan sampel berupa unit lahan melalui beberapa tahapan yakni sebagai berikut: (1) Membuat peta kajian kesesuaian lahan pada tahap regional wilayah peruntukkan pengembangan/perluasan lokasi TPA sampah dengan memperhatikan batas wilayah yang telah ditetapkan dan kemudian membuat peta satuan lahan dengan cara tumpang susun (overlay) dengan peta administrasi, peta kemiringan lahan, peta geologi, hidrologi, peta penggunaaan lahan, peta bentuk lahan, dan peta perairan (sungai); (2) Menentukan tingkat kelayakan regional setiap satuan lahan berdasarkan SNI 03-32411994 untuk mengetahui zona kelayakan calon lokasi TPA sampah; (3) Menentukan sampel penelitian yang dilakukan dengan cara menentukan populasi penelitian fisik lahan yakni, satuan lahan wilayah penelitian yang ditentukan berdasarkan hasil tumpang susun (overlay). Sampel penelitian fisik lahan ditentukan pada unit lahan di wilayah pengembangan/perluasan lokasi TPA; (4) Mengambil sampel tanah untuk menilai permeabilitas tanah di laboratorium; (5) Menganalisis data fisik lahan berdasarkan hasil pengamatan dan pengukuran satuan lahan di tingkat lapang serta hasil analisis laboratorium, dilanjutkan dengan pengharkatan untuk mendapatkan kelas lahan biofisik lokasi TPA sampah; (6) Melakukan interpretasi melalui peta wilayah penelitian dan potensi kesesuaian lokasi TPA berdasarkan batasan penelitian.

$$
\text { Pengumpulan data tanggapan }
$$
masyarakat diperoleh melalui beberapa tahapan yaitu: (1) Menyediakan peta wilayah penelitian TPA sampah di Kota Kotamobagu untuk menentukan lokasi pengambilan sampel yaitu masyarakat di sekitar lokasi pengembangan/perluasan TPA sampah dan masyarakat pemulung; (2) Populasi 
ditentukan dengan metode purposive sampling (teknik penentuan sampel dengan pertimbangan tertentu). Populasi yakni, masyarakat kelompok usia produktif (15-64 tahun) yang terbagi atas kelompok keluarga masyarakat sekitar yang bermukim di sekitar lokasi pengembangan/perluasan TPA sampah pada jarak 500-1500 meter dan masyarakat pemulung yang berada/tinggal di lokasi TPA sampah; (3) Teknik pemilihan sampel menggunakan desain sampling acak sederhana berdasarkan wilayah yang telah dibatasi oleh batas administrasi dan sosial. Jumlah sampel yang diambil menggunakan formula Slovin dalam Setiawan (2007), dengan rumus yang digunakan sebagai berikut:

$$
\begin{aligned}
& n=\frac{N}{N \cdot d^{2}+1} \\
& \text { dimana: } \\
& n \quad=\text { Ukuran Sampel } \\
& N \quad=\text { Populasi } \\
& d \quad=\text { galat pendugaan }(0,1)
\end{aligned}
$$

(4) Teknik pengumpulan data dilakukan dengan angket dan wawancara dalam metode kuesioner berbentuk skala Likert di samping pengamatan atas aktivitas masyarakat. Responden menjawab butir-butir pertanyaan dalam daftar pertanyaan yang telah disediakan jawabannya; (5) Menganalisis tanggapan berdasarkan data yang dikumpulkan dari kuesioner di lapangan. Selanjutnya ditabulasi dan di deskripsikan.

\section{Analisa Data}

Berdasarkan metode penelitian, maka dilakukan: (1) analisis deskriptif kuantitatif kesesuaian lahan fisik lokasi di wilayah peruntukkan pengembangan lokasi TPA sampah melalui metode pengharkatan yang mengacu pada kriteria-kriteria tahapan pada SNI 03-3241-1994 yakni tahapan kelayakan regional dan penyisih; (2) analisis deskriptif kuantitatif tanggapan masyarakat terhadap keberadaan lokasi TPA sampah melalui penilaian persepsi dan pengetahuan masyarakat yang diukur dari indikatorindikator variabel persepsi dan pengetahuan. Pengukuran data responden melalui pengharkatan dari setiap jawaban pertanyaan dalam kuesioner dengan menggunakan skala Likert lalu ditabulasikan dan dideskriptifkan. Tingkat signifikansi dari setiap responden terhadap pertanyaan tidak diuji dengan test statistik; dan (3)

Analisis deskriptif kesesuaian lokasi TPA sampah melalui metode checklist yakni, membandingkan antara kelas kesesuaian lahan secara fisik dan kelas tanggapan masyarakat untuk mengetahui lokasi yang sesuai untuk TPA sampah.

\section{HASIL DAN PEMBAHASAN}

Kesesuaian Lahan Secara Geofisik Pada Tahap Kelayakan Regional dan Penyisih

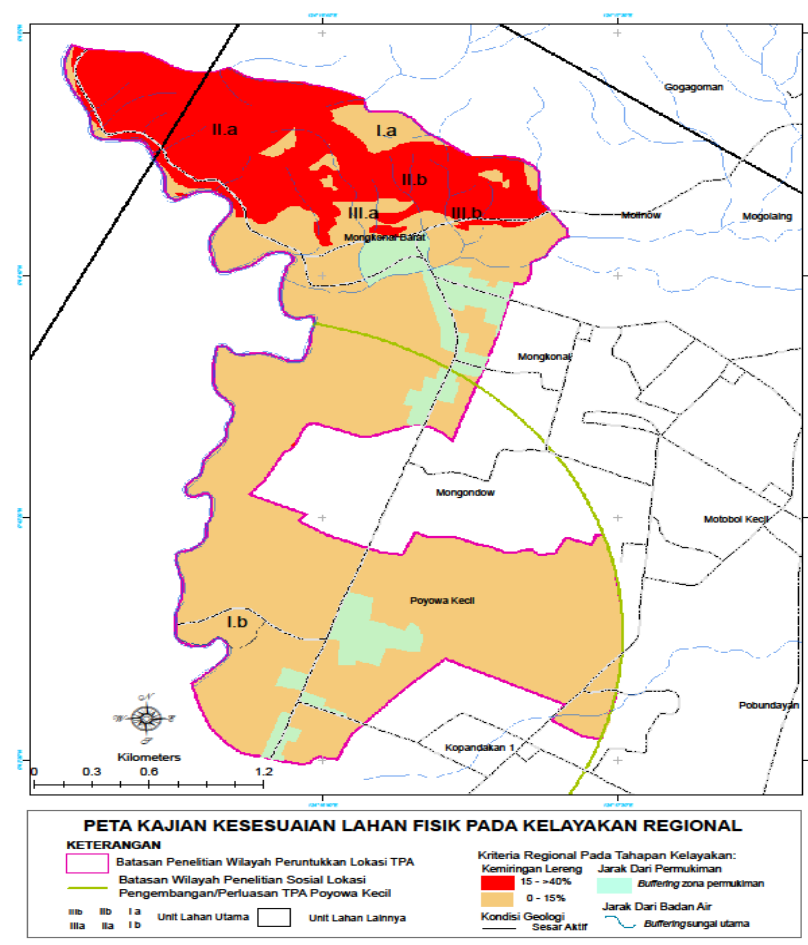

Gambar 2. Peta Kajian Kesesuaian Lahan Fisik Pada Kelayakan Regional

Pada Gambar 2, dapat digambarkan secara umum wilayah kajian peruntukkan pengembangan lokasi TPA sampah di Kota Kotamobagu yang berada di dua lokasi yakni, lokasi pengembangan/perluasan TPA sampah Poyowa Kecil yang diwakili oleh unit lahan I.b dimana lokasi TPA eksisting Poyowa Kecil berada pula pada lokasi tersebut dan lokasi pengembangan TPA di Mongkonai 
Barat yang diwakili oleh unit lahan I.a, II.a, dan III.a serta unit lahan II.b dan III.b.

Pengamatan dan pengukuran dilapangan masing karakteristik variabel yaitu variabel khusus, geofisik dan keruangan dilakukan pada unit lahan yang telah ditentukan kemudian dikolaborasikan sehingga mendapatkan hasil pengukuran berdasarkan pembagian lokasi pengembangan lokasi TPA yakni Poyowa Kecil dan Mongkonai Barat.

Penilaian kesesuaian lahan geofisik meliputi tahap kelayakan regional dan kelayakan penyisih. Secara umum, gambaran kajian kesesuaian pada tahapan kelayakan regional. Untuk penilaian dilakukan pengharkatan dengan membagi kelas kelayakan tahap regional menjadi layak untuk TPA sampah dan tidak layak untuk TPA sampah seperti tersaji pada Tabel 1 .

Tabel 1. Pengukuran Karakteristik Variabel Khusus Pada Kriteria Regional

\begin{tabular}{|c|c|c|c|c|c|c|}
\hline \multicolumn{7}{|c|}{ Lokasi TPA Sampah berdasarkan Unit Lahan } \\
\hline \multirow{3}{*}{ Variabel } & \multicolumn{6}{|c|}{ Hasil Pengharkatan } \\
\hline & \multicolumn{6}{|c|}{ Unit Lahan Utama } \\
\hline & I.a & I.b & II.a & II.b & III.a & III.b \\
\hline \multicolumn{7}{|l|}{ Khusus } \\
\hline \multicolumn{7}{|l|}{ Kemiringan } \\
\hline Lereng & 1 & 1 & 0 & 0 & 1 & 0 \\
\hline Kondisi Geologi & 1 & 1 & 0 & 1 & 1 & 1 \\
\hline Jarak Terhadap & & & & & & \\
\hline Badan Air & 1 & 0 & 0 & 0 & 0 & 0 \\
\hline Jarak dari & & & & & & \\
\hline Pemukiman & 1 & 0 & 1 & 0 & 0 & 0 \\
\hline Jarak dari & & & & & & \\
\hline Lapangan Terbang & 1 & 1 & 1 & 1 & 1 & 1 \\
\hline Jumlah & 5 & 3 & 2 & 2 & 3 & 2 \\
\hline
\end{tabular}

Menurut Drake dan Pereira (2002), hasil pengharkatan pada Tabel 10 merupakan faktor pembatas utama (indikator khusus) dalam penetapan lokasi TPA sampah yang berwawasan lingkungan, sehingga dikatakan layak untuk TPA sampah apabila harkat mencapai jumlah maksimal (harkat lima) dan dapat dikatakan tidak layak jika dibawah jumlah maksimal.

Berdasar hasil pengharkatan pada kriteria regional (Tabel 1), diketahui bahwa lokasi unit lahan I.b yang mewakili lokasi pengembangan/perluasan TPA sampah Poyowa Kecil berada pada kategori tidak layak, sedangkan pada lokasi pengembangan
TPA di Mongkonai Barat terdapat unit lahan utama I.a yang masuk pada kategori layak. Selanjutnya unit lahan potensial layak I.a sebagai lokasi pengembangan TPA di Mongkonai Barat seperti yang terlihat pada Gambar 2.

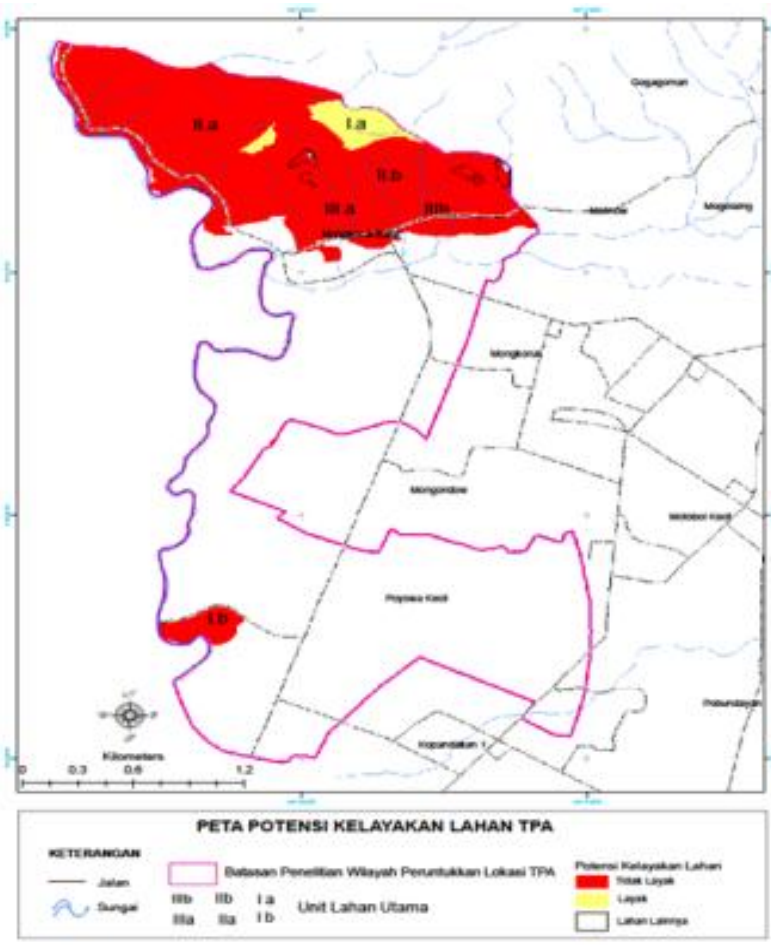

Gambar 2. Peta Potensi Kelayakan Lahan TPA Kota Kotamobagu

Pengharkatan dilakukan dengan membagi kelas kesesuaian lahan secara fisik menjadi tiga kelas yaitu; sangat sesuai (kategori baik), cukup sesuai (kategori sedang) dan kurang sesuai (kategori jelek).

Berdasarkan hasil perhitungan, interval kelas kesesuaian lahan secara fisik dapat diketahui pada Tabel 2. Hasil kelas pengharkatan pada kelas kesesuaian lahan potensial secara fisik pada kriteria penyisih, menunjukkan bahwa lokasi unit lahan pada wilayah peruntukkan pengembangan lokasi TPA sampah di Kota Kotamobagu berada pada pada kelas kesesuaian II dengan kategori cukup sesuai.

Berdasarkan penilaian pada Tabel 3 dan 4, diketahui total nilai 212 untuk calon lokasi TPA pengebangan/perluasan TPA Poyowa Kecil dan nilai 240 untuk lokasi pengembangan TPA Mongkonai Barat. 
Tabel 2. Kelas Kesesuian Lahan Potensial Lokasi TPA Sampah

\begin{tabular}{ccc}
\hline Kelas kesesuaian & Kelas interval & Keterangan \\
\hline I & $301-410$ & Sangat sesuai \\
II & $195-300$ & Cukup sesuai \\
III & $86-194$ & Kurang sesuai \\
\hline
\end{tabular}

Data statistik deskriptif pada Tabel 1,3 dan 4, dari 34 item (kriteria regional masingmasing terdapat 5 item variabel khusus untuk unit lahan pengembangan/perluasan lokasi TPA di Poyowa Kecil dan unit lahan pengembangan lokasi TPA di Mongkonai Barat, kriteria penyisih masing-masing terdapat 12 item untuk variabel umum, geofisik, keruangan lokasi pengembangan/perluasan TPA di Poyowa Kecil dan lokasi pengembangan TPA Mongkonai Barat.

Tabel 3. Karakteristik Variabel Kriteria Penyisih Calon Lokasi Perluasan TPA Sampah Poyowa Kecil

\begin{tabular}{|c|c|c|c|c|c|c|c|c|}
\hline \multirow[b]{2}{*}{ Variabel } & \multirow{2}{*}{$\begin{array}{c}\text { Hasil } \\
\text { Pengukuran }\end{array}$} & \multirow{2}{*}{$\begin{array}{c}\text { Hasil } \\
\text { Harkat }\end{array}$} & \multicolumn{5}{|c|}{ Interpretasi Kelayakan } & \multirow{2}{*}{$\begin{array}{l}\text { Nilai } \\
\text { Data }\end{array}$} \\
\hline & & & $\frac{B s}{5}$ & $\mathrm{~B}$ & s & $\mathrm{Br}$ & Brs & \\
\hline \multicolumn{9}{|l|}{ Umum } \\
\hline $\begin{array}{l}\text { Batas } \\
\text { Administrasi }\end{array}$ & $\begin{array}{l}\text { dalam batas } \\
\text { administrasi }\end{array}$ & 50 & $\checkmark$ & & & & & 5 \\
\hline $\begin{array}{l}\text { Pemilikan hak } \\
\text { atas tanah }\end{array}$ & $\begin{array}{l}\text { lebih dari } \\
\text { satu } \\
\text { kepemilikan }\end{array}$ & 9 & & & & $\checkmark$ & & 2 \\
\hline $\begin{array}{l}\text { Jumlah pemilik } \\
\text { tanah }\end{array}$ & $4-5 \mathrm{KK}$ & 15 & & $\checkmark$ & & & & 4 \\
\hline \multicolumn{9}{|l|}{$\begin{array}{l}\text { Lingkungan } \\
\text { Geofisik }\end{array}$} \\
\hline $\begin{array}{l}\text { Permeabilitas } \\
\text { tanah }\end{array}$ & $>10^{-6} \mathrm{~cm} / \mathrm{dtk}$ & 5 & & & & & $\sqrt{ }$ & 1 \\
\hline $\begin{array}{l}\text { Pemanfaatan air } \\
\text { tanah }\end{array}$ & $\begin{array}{l}\text { dimanfaatkan } \\
\text { dengan batas } \\
\text { hidrolis }\end{array}$ & 15 & & & $\checkmark$ & & & 3 \\
\hline $\begin{array}{l}\text { Kedalaman air } \\
\text { tanah }\end{array}$ & $<10$ meter & 40 & & $\checkmark$ & & & & 4 \\
\hline Intensitas hujan & $\begin{array}{l}>1000 \\
\mathrm{~mm} / \text { tahun }\end{array}$ & 3 & & & & & v & 1 \\
\hline Bahaya banjir & $\begin{array}{l}\text { tidak ada } \\
\text { banjir }\end{array}$ & 20 & $\checkmark$ & & & & & 5 \\
\hline $\begin{array}{l}\text { Transport } \\
\text { sampah }\end{array}$ & $\begin{array}{l}\text { antara 16-30 } \\
\text { menit }\end{array}$ & 40 & & v & & & & 4 \\
\hline \multicolumn{9}{|l|}{ Keruangan } \\
\hline Kawasan lindung & $\begin{array}{l}\text { berada } \\
\text { didalam } \\
\text { kawasana } \\
\text { lindung }\end{array}$ & 2 & & & & & $\checkmark$ & 1 \\
\hline $\begin{array}{l}\text { Kebisingan dan } \\
\text { Bau }\end{array}$ & $\begin{array}{l}\text { zona } \\
\text { penyangga }\end{array}$ & 10 & & & $\checkmark$ & & & 3 \\
\hline $\begin{array}{l}\text { Kawasan } \\
\text { pertanian }\end{array}$ & $\begin{array}{l}\text { tanah } \\
\text { pertanian } \\
\text { produktif }\end{array}$ & 3 & & & & & $\checkmark$ & 1 \\
\hline Jumlah & & 212 & & & & & & 34 \\
\hline
\end{tabular}

Tabel 4. Karakteristik Variabel Kriteria Penyisih Calon Lokasi TPA Sampah di Mongkonai Barat.

\begin{tabular}{|c|c|c|c|c|c|c|c|c|}
\hline \multirow[b]{2}{*}{ Variabel } & \multirow{2}{*}{$\begin{array}{c}\text { Hasil } \\
\text { Pengukuran }\end{array}$} & \multirow{2}{*}{$\begin{array}{l}\text { Hasil } \\
\text { Harkat }\end{array}$} & \multicolumn{5}{|c|}{ Interpretasi Kelayakan } & \multirow{2}{*}{$\begin{array}{l}\text { Nilai } \\
\text { Data }\end{array}$} \\
\hline & & & $\frac{\mathrm{Bs}}{5}$ & $\mathrm{~B}$ & 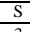 & $\mathrm{Br}$ & Brs & \\
\hline \multicolumn{9}{|l|}{ Umum } \\
\hline $\begin{array}{l}\text { Batas } \\
\text { Administrasi }\end{array}$ & $\begin{array}{l}\text { dalam batas } \\
\text { administrasi }\end{array}$ & 50 & $\checkmark$ & & & & & 5 \\
\hline $\begin{array}{l}\text { Pemilikan hak } \\
\text { atas tanah }\end{array}$ & $\begin{array}{l}\text { lebih dari } \\
\text { satu } \\
\text { kepemilikan }\end{array}$ & 9 & & & & $\checkmark$ & & 2 \\
\hline $\begin{array}{l}\text { Jumlah pemilik } \\
\text { tanah }\end{array}$ & $4-5 \mathrm{KK}$ & 15 & & v & & & & 4 \\
\hline \multicolumn{9}{|l|}{$\begin{array}{l}\text { Lingkungan } \\
\text { Geofisik }\end{array}$} \\
\hline $\begin{array}{l}\text { Permeabilitas } \\
\text { tanah }\end{array}$ & $\begin{array}{l}>10^{-6} \\
\mathrm{~cm} / \mathrm{dtk}\end{array}$ & 5 & & & & & $\checkmark$ & 1 \\
\hline $\begin{array}{l}\text { Pemanfaatan air } \\
\text { tanah }\end{array}$ & $\begin{array}{l}\text { dimanfaatkan } \\
\text { dengan batas } \\
\text { hidrolis }\end{array}$ & 15 & & & $\checkmark$ & & & 3 \\
\hline $\begin{array}{l}\text { Kedalaman air } \\
\text { tanah }\end{array}$ & $\geq 10$ meter & 50 & $\checkmark$ & & & & & 5 \\
\hline Intensitas hujan & $\begin{array}{l}>1000 \\
\mathrm{~mm} / \text { tahun }\end{array}$ & 3 & & & & & $\checkmark$ & 1 \\
\hline Bahaya banjir & $\begin{array}{l}\text { tidak ada } \\
\text { banjir }\end{array}$ & 20 & $\checkmark$ & & & & & 5 \\
\hline $\begin{array}{l}\text { Transport } \\
\text { sampah }\end{array}$ & $\begin{array}{l}\text { antara 15-30 } \\
\text { menit }\end{array}$ & 40 & & $\checkmark$ & & & & 4 \\
\hline \multicolumn{9}{|l|}{ Keruangan } \\
\hline Kawasan lindung & $\begin{array}{l}\text { di luar } \\
\text { kawasan } \\
\text { lindung }\end{array}$ & 20 & $\checkmark$ & & & & & 5 \\
\hline $\begin{array}{l}\text { Kebisingan dan } \\
\text { Bau }\end{array}$ & $\begin{array}{l}\text { zona } \\
\text { penyangga } \\
\text { terbatas }\end{array}$ & 10 & & & & & & 3 \\
\hline $\begin{array}{l}\text { Kawasan } \\
\text { pertanian }\end{array}$ & $\begin{array}{l}\text { tanah } \\
\text { pertanian } \\
\text { produktif }\end{array}$ & 3 & & & & & $\checkmark$ & 1 \\
\hline Jumlah & & 240 & & & & & & 39 \\
\hline
\end{tabular}

Pengharkatan kelayakan penyisih, dilakukan dengan membagi kelas kelayakan lahan secara fisik menjadi lima kelas yaitu; 1) baik sekali (Bs), 2) baik (B), sedang (S), buruk (Br), buruk sekali (Brs) seperti yang tersaji pada Tabel 11 dan 12. Penentuannya dilakukan dengan metode checklist setelah dilakukan pengharkatan dari skor yang diperoleh (Tamod 2008).

Hasil pengukuran dan pengharkatan variabel umum, lingkungan geofisik dan keruangan pada kriteria penyisih pada wilayah peruntukkan pengembangan lokasi TPA sampah di Kota Kotamobagu yakni, lokasi pengembangan/perluasan TPA sampah di Desa Poyowa Kecil Kecamatan Kotamobagu Selatan dan lokasi pengembangan TPA sampah di Kelurahan Mongkonai Barat Kecamatan Kotamobagu Barat yang terdiri dari variabel khusus dengan item-item karakteristik variabel berupa batas (1) administrasi; (2) pemilikan hak atas tanah; (3) jumlah pemilik tanah, variabel lingkungan geofisik dengan item-item karakteristik variabel berupa (1) permeabilitas tanah; (2) pemanfaatan air tanah; (3) kedalaman air tanah; (4) intensitas hujan; (5) bahaya banjir; (6) transport sampah dan variabel keruangan dengan item-item karakteristik variabel berupa (1) kawasan lindung; (2) kebisingan dan bau; (3) kawasan pertanian dapat dilihat pada Tabel 3 dan 4 .

Berdasarkan interpretasi kesesuaian item-item karakteristik variabel pada Tabel 12, diketahui bahwa untuk lokasi pengembangan TPA sampah di Poyowa Kecil berada pada kategori kelas Baik sekali (Bs) pada dua item karakteristik yaitu, batas administrasi dan bahaya banjir. Sedangkan pada kategori kelas baik (B) terdapat dua item karakteristik yaitu, jumlah pemilik tanah dan transport sampah, kelas sedang (S) terdapat dua item karakterik yaitu pemanfaatan air tanah dan zona penyangga dan satu item karakteristik yakni, pemilikan hak atas tanah berada pada kategori kelas buruk (br) serta lima karakteristik yang tersisa dikategori kelas buruk sekali (Brs) yaitu, permeabilitas tanah, kedalaman air tanah, intensitas hujan, kawasan lindung dan kawasan pertanian. 
Secara umum hasil interpretasi kesesuaian kelas masing-masing item-item karakteristik variabel pada kriteria penyisih di dominasi oleh kategori kelas kesesuaian buruk sekali (Brs) sebanyak lima item, buruk (Br) dengan satu item, sedang (S) dengan 2 item, baik (B) dengan item dan baik sekali (Bs) 2 item karakteristik variabel.

Sedangkan pada lokasi pengembangan TPA Mongkonai Barat untuk hasil interpretasi kesesuaian lahan untuk kriteria penyisih pada masing-masing item karakteristik variabel pada Tabel 12, terlihat bahwa kelas kesesuaian pada masing-item karakteristik ini terdapat tiga item karakteristik pada kategori kelas baik sekali (Bs), dua item karakteristik pada kategori kelas baik (B), satu item kategori kelas sedang (S), satu item kategori pada kelas buruk (Br) dan tiga item kategori buruk sekali (Brs). Dalam penilaian pada Tabel 13, diketahui calon lokasi layak potensial pengembangan lokasi TPA Mongkonai Barat mendapatkan total nilai tertinggi yaitu, 240 dan untuk calon lokasi pengembangan/perluasan TPA Poyowa Kecil mendapatkan total nilai 212. Unit lahan yang memperoleh total nilai tertinggi diprioritaskan sebagai calon lokasi TPA sampah potensial.

\begin{tabular}{|c|c|c|}
\hline \multirow[b]{2}{*}{ Variabel } & \multicolumn{2}{|c|}{ Pengharkatan } \\
\hline & $\begin{array}{c}\text { Calon Lokasi } \\
\text { Pengembangan/ } \\
\text { Perluasan TPA } \\
\text { Poyowa Kecil }\end{array}$ & $\begin{array}{c}\text { Calon Lokasi } \\
\text { Pengembangan TPA } \\
\text { Mongkonai Barat }\end{array}$ \\
\hline Umum & & \\
\hline $\begin{array}{l}\text { Batas } \\
\text { Administrasi } \\
\text { Pemilikan Hak } \\
\text { Atas Tanah } \\
\text { Jumlah Pemilik } \\
\text { Tanah } \\
\end{array}$ & $\begin{array}{c}50 \\
9 \\
15\end{array}$ & $\begin{array}{c}50 \\
9 \\
15\end{array}$ \\
\hline Geofisik & & \\
\hline $\begin{array}{l}\text { Permeabilitas } \\
\text { Tanah } \\
\text { Pemanfaatan } \\
\text { Air Tanah } \\
\text { Kedalaman Air } \\
\text { Tanah } \\
\text { Intensitas Hujan } \\
\text { Bahaya Banjir } \\
\text { Transport } \\
\text { Sampah }\end{array}$ & $\begin{array}{c}5 \\
15 \\
5 \\
3 \\
20 \\
40\end{array}$ & $\begin{array}{c}5 \\
15 \\
50 \\
3 \\
20 \\
40\end{array}$ \\
\hline Keruangan & & \\
\hline $\begin{array}{l}\text { Daerah Lindung } \\
\text { Zona } \\
\text { Penyangga } \\
\text { Kawasan } \\
\text { Pertanian } \\
\end{array}$ & $\begin{array}{c}2 \\
10 \\
3\end{array}$ & $\begin{array}{c}20 \\
20 \\
3\end{array}$ \\
\hline Jumlah & 212 & 240 \\
\hline
\end{tabular}

\section{Tanggapan Masyarakat}

Tanggapan masyarakat terhadap lokasi TPA sampah di Kota Kotamobagu perlu dikaji untuk menjadi bahan pertimbangan dalam menilai keberadaan TPA, disamping penilaian kesesuaian fisik lahan.

Dalam hal ini, masyarakat dapat menerima dengan segala konsekuensinya, menerima dengan konsekuensi tertentu atau bahkan menolak sama sekali keberadaan TPA di lingkungan mereka. Tanggapan masyarakat ini terkait erat dengan tingkat pengetahuan dan persepsi masyarakat itu sendiri, untuk mengetahui tanggapan masyarakat terkait keberadaan TPA sampah di Kota Kotamobagu yakni, dengan menganalisis tingkat pengetahuan dan persepsi masyarakat yang berada di dalam dan sekitar wilayah pengembangan lokasi TPA sampah di Kota Kotamobagu dan dideskriptifkan.

Populasi yakni, masyarakat kelompok usia produktif (kelompok umur 15-64 tahun) dalam satu keluarga. Kelompok usia produktif dipilih berdasarkan kenyataan bahwa mayoritas penduduk pada dua kecamatan yakni, Kecamatan Kotamobagu Selatan dan Kotamobagu Barat masuk dalam kategori kelompok umur ini (Gambar 2 dan Tabel 5).

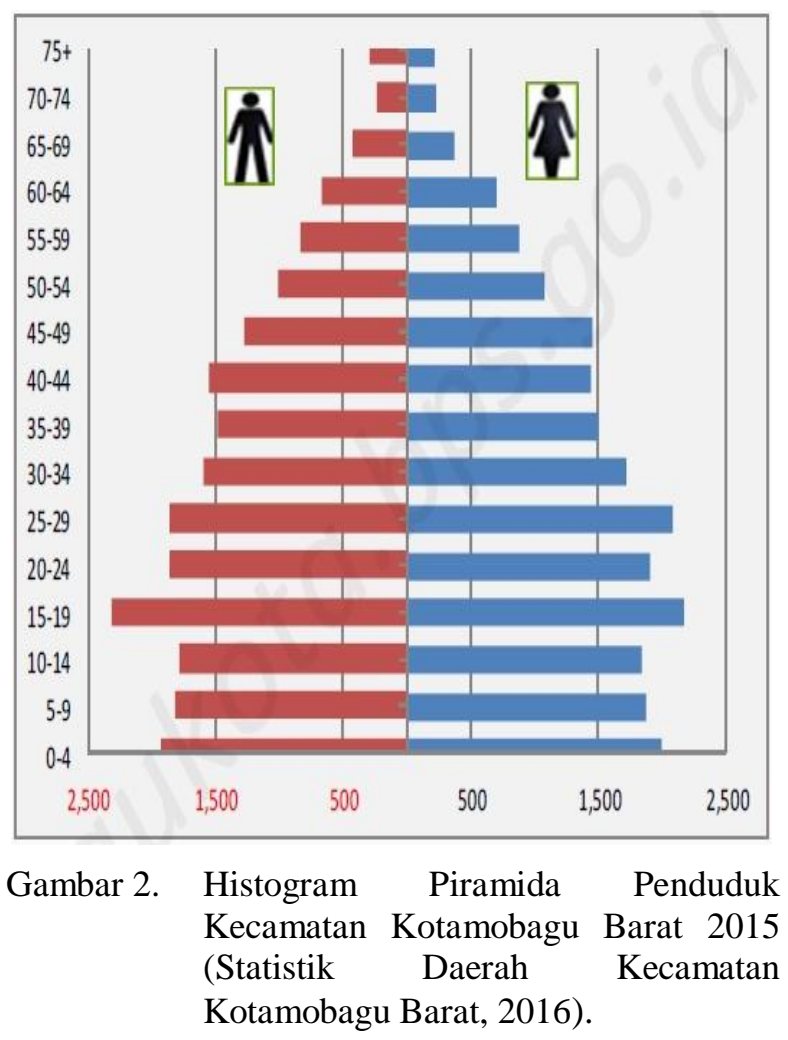


Kelompok umur ini menyebar di tiaptiap keluarga yang bertempat tinggal disekitar lokasi unit lahan pengembangan/perluasan TPA dengan jarak (range) permukiman 500$1500 \mathrm{~m}$. Jarak permukiman ini dipilih karena pendugaan potensi dampak dari TPA sampah secara langsung maupun tidak langsung dengan pertimbangan bahwa di wilayah ini sudah pernah ada TPA sampah yakni, TPA eksisting Poyowa Kecil sehingga diasumsikan pendugaan potensi dampak lokasi pengembangan/perluasan yang berdekatan dan atau berbatasan langsung dengan lokasi TPA eksisting ini, terhadap masyarakat sekitarnya dan pemulung sama halnya dengan potensi dampak akan keberadaan TPA eksisting sebelumnya.

Tabel 5. Jumlah Penduduk Menurut Kelompok Umur dan Jenis Kelamin di Kecamatan Kotamobagu Selatan, 2015. (Statistik Daerah Kecamatan Kotamobagu Barat, 2016)

\begin{tabular}{cccc}
\hline Kelompok & \multicolumn{2}{c}{ Jenis Kelamin } & \multirow{2}{*}{ Jumlah } \\
\cline { 2 - 3 } Umur & Laki-Laki & Perempuan & \\
\hline $0-4$ & 1.407 & 1.448 & 2.855 \\
$5-9$ & 1.395 & 1.348 & 2.743 \\
$10-14$ & 1.379 & 1.281 & 2.66 \\
$15-19$ & 1.348 & 1.419 & 2.767 \\
$20-24$ & 1.24 & 1.064 & 2.304 \\
$25-29$ & 1.458 & 1.357 & 2.815 \\
$30-34$ & 1.433 & 1.289 & 2.722 \\
$35-39$ & 1.294 & 1.214 & 2.508 \\
$40-44$ & 1.193 & 1.123 & 2.316 \\
$45-49$ & 1.092 & 1.014 & 2.106 \\
$50-54$ & 857 & 797 & 1.654 \\
$55-59$ & 656 & 603 & 1.259 \\
$60-64$ & 484 & 453 & 937 \\
$65+$ & 609 & 621 & 1.23 \\
\hline Jumlah & 15.845 & 15.031 & 30.876 \\
\hline Sumber: Kotamobagu Selatan Dalam Angka 2016.
\end{tabular}

Sumber: Kotamobagu Selatan Dalam Angka, 2016.

Pemukiman yang berada dalam jarak (range) 500-2000 ini tersebar di beberapa wilayah yakni, Desa Poyowa Kecil dengan jumlah keluarga 902 KK, Desa Kopandakan I dengan jumlah keluarga 882, Kelurahan Mongondow dengan jumlah keluarga $500 \mathrm{KK}$ dan Kelurahan Mongkonai Barat dengan jumlah $675 \mathrm{KK}$.

Pengambilan sampel yang dilakukan secara acak sederhana (setiap anggota sampel yang diambil dari populasi yang telah ditentukan sebelumnya mempunyai peluang yang sama) dari jumlah sampel yakni, Desa Poyowa Kecil sebanyak 90 respondendan 96 responden yang terbagi secara proporsional untuk Desa Kopandakan I, Kelurahan Mongondow dan Kelurahan Mongkonai Barat masing-masing sebanyak 32 responden serta 10 responden pemulung untuk lokasi pengembangan/perluasan TPA sampah Poyowa Kecil.

Untuk lokasi pengembangan TPA sampah di wilayah Mongkonai Barat, jumlah yang di dapatkan sebanyak 87 responden di Kelurahan Mongkonai Barat sebagaimana yang terlihat pada Tabel 5 .

\section{Tanggapan Responden Terhadap Lokasi TPA Sampah}

Persepsi merupakan suatu proses yang ditempuh individu-individu untuk mengorganisasikan dan menafsirkan kesan indera mereka agar memberi makna (Tamod, 2008).

Dalam penelitian ini, pengertian persepsi tersebut disintesiskan dari indikatorindikator berupa; (1) dampak negatif TPA sampah meliputi pencemaran lingkungan, kenyamanan tempat tinggal dan penurunan kesehatan; (2) dampak positif TPA sampah meliputi sumber mata pencaharian, manfaat hasil olahan, pengurangan sampah yang berhamburan, manfaat TPA; (3) Keberadaan TPA sampah meliputi kondisi TPA sampah eksisting dan keberlanjutannya, rasa aman dari resiko bencana, pengembangan potensi lahan sekitar; (4) Pengelolaan TPA sampah meliputi sarana dan prasarana penunjang, sistem pengelolaan TPA, kenyamanan atas lalu lintas sampah. Persepsi juga bertalian dengan pengetahuan yang dipandang sebagai kemampuan seseorang untuk mengenal, mengingat, mereproduksi bahan pengetahuan yang pernah didapatkannya.

Poedjawijatna (1991) menyatakan bahwa macam pengetahuan dipandang dari pengetahuan khusus yang berkenaan dengan hal tertentu dan pengetahuan umum yang berlaku bagi seluruh macam-macam dan masing-masing obyek dalam keanekaragamannya dan menjadi milik manusia berlandaskan pengalaman.

Pengetahuan masyarakat sekitar TPA dan pemulung diukur berdasarkan indikator pengetahuan masyarakat dan pemulung 
berupa wawasan pengelolaan, pengolahan sampah dan indikator pengetahuan tentang keberadaan dan fungsi TPA sampah.

Tabel 6. Kelas Tanggapan (Persepsi) Masyarakat Terhadap Keberadaan Calon Lokasi Pengembangan/Perluasan TPA Poyowa Kecil

\begin{tabular}{ccc}
\hline Kelas Tanggapan & Kelas Interval & keterangan \\
\hline Positif & $20-25$ & Menerima \\
Netral & $11-19$ & Netral \\
Negatif & $5-10$ & Menolak \\
\hline
\end{tabular}

Tanggapan masyarakat dihitung dari total nilai yang diperoleh pada indikator keberadaan TPA dengan membuat interval persepsi seperti pada Tabel 6, kemudian dielaborasikan dengan presentase pengetahuan masyarakat sekitar TPA dan pemulung di lokasi TPA sampah Poyowa Kecil.

Secara rinci pada Gambar 3, terlihat persentase dominan dari indikator persepsi lainnya yakni: (1) penilaian positif terhadap dampak negatif yang yang timbul akibat adanya TPA sampah buat masyarakat dan lingkungan sekitarnya yang berkisar antara 56,25-73,33\% menilai positif berdampak, sementara pemulung lebih cenderung menilai netral (70\%); (2) penilaian dampak positif yang ditimbulkan akibat adanya TPA sampah oleh masyarakat sekitar cenderung dinilai positif dengan kisaran 59,38$76,67 \%$, sebagian lagi yakni masyarakat yang berada di wilayah Kopandakan I dan Mongkonai Barat lebih cenderung netral (37,50-40.63\%), sementara sebagian pemulung memberikan nilai positif dan dan sebagian lagi menilai netral dan (3) penilaian mengenai pengelolaan TPA, secara umum masyarakat sekitar TPA dan pemulung yang cenderung menilai positif dengan kisaran $56,25-83,33 \%$, kecuali masyarakat Mongondow yang memberikan nilai netral.

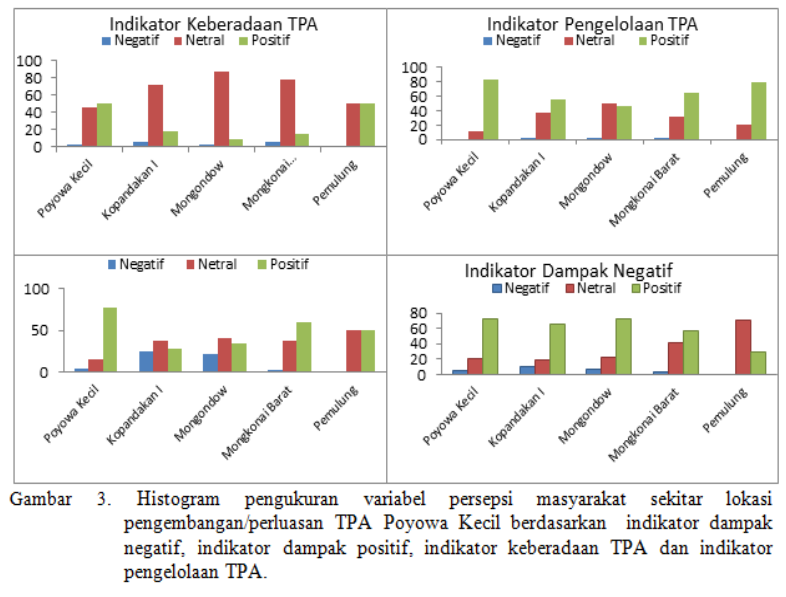

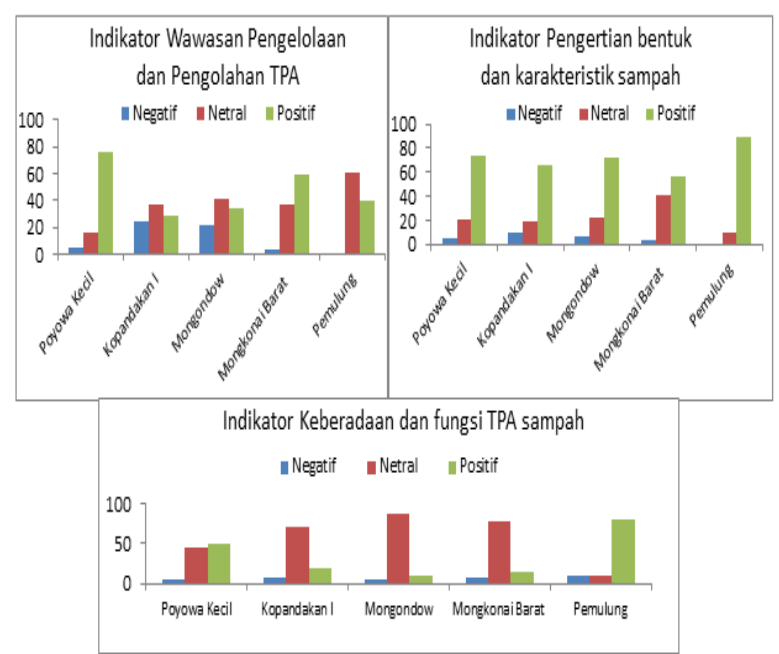

Gambar 4. Histogram pengukuran indikator pengertian bentuk dan karakteristik sampah, indikator wawasan pengelolaan dan pengolahan sampah serta indikator keberadaan dan fungsi TPA sampah, variabel pengetahuan masyarakat sekitar lokasi pengembangan/perluasan TPA Poyowa Kecil.

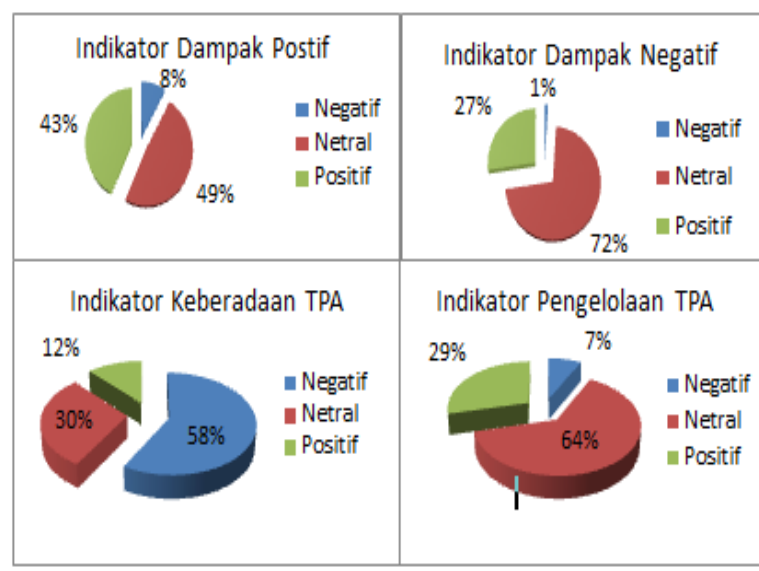

Gambar 5. Histogram pengukuran variabel persepsi masyarakat sekitar lokasi pengembangan TPA Mongkonai Barat berdasarkan indikator dampak negatif, indikator dampak

Tanggapan responden masyarakat terhadap keberadaan TPA dil wilayah lokasi pengembangan TPA di kelurahan Mongkonai Barat pada umumnya menolak kehadiran TPA sampah di wilayah yang mereka tinggali.

Hal ini terlihat pula dari kecenderungan responden memberikan penilaian netral terhadap indikator persepsi yakni: (1) penilaian indikator dampak negatif dengan kisaran $70 \%$; (2) penilaian indikator dampak positif berkisar 45\%; (3) penilaian indikator pengelolaan TPA, sedangkan pada indikator (4) penilaian keberadaan TPA sampah, respondenPersepsi masyarakat di wilayah pengembangan lokasi TPA apabila dihubungkan dengan pengetahuan masyarakat bertalian dengan penilaian pengetahuan keberadaan dan fungsi TPA sampah dimana pengetahuan responden masyarakat di 
wilayah pengembangan TPA (Kelurahan Mongkonai Barat) ini tergolong rendah (kategori negatif) $44,83 \%$, hal ini berbanding terbalik dengan penilaian indikator pengetahuan responden tentang arti, bentuk dan karakteristik sampah serta indikator wawasan pengelolaan dan pengolahan TPA sampah yang masuk kategoriber pengetahuan tinggi (penilaian positif) dengan persentase masing sebesar $84,66 \%$ dan $57,47 \%$, seperti yang tersaji pada Gambar 6.

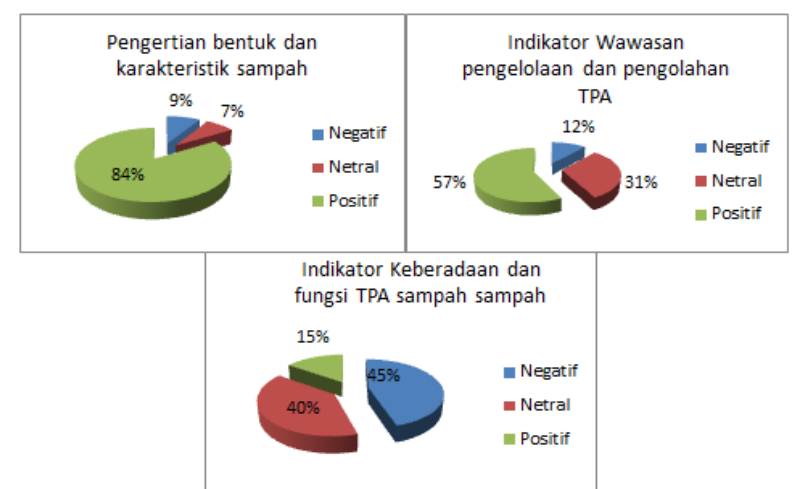

Gambar 6. Histogram pengukuran indikator pengertian bentuk dan karakteristik sampah, indikator wawasan pengelolaan dan pengolahan sampah serta indikator keberadaan dan fungsi TPA sampah, variabel pengetahua masyarakat sekitar lokasi pengembangan TPA Mongkonai Barat.

\section{Kesesuaian Lahan Untuk Lokasi TPA Sampah Kota Kotamobagu}

Analisis kesesuaian lahan dilaksanakan untuk menentukan tingkat kesesuaian lahan lokasi TPA sampah berdasarkan hasil analisis kesesuaian fisik lahan dan analisis kesesuaian sosial masyarakat.

Hasil analisis kesesuaian lahan dibagi menjadi tiga kelas, yaitu sesuai, cukup sesuai dan tidak sesuai. Sedangkan untuk Penentuannya dilakukan dengan metode checklist, yaitu membandingkan kelas kesesuaian lahan secara fisik dan kelas tanggapan masyarakat seperti yang tersaji pada Tabel 6 dan 7.

Tabel 7. Kesesuaian Lahan Untuk Lokasi Pengembangan/Perluasan TPA Sampah Poyowa Kecil

\begin{tabular}{|c|c|c|c|c|c|}
\hline \multirow[t]{2}{*}{$\begin{array}{l}\text { Responden } \\
\text { Masyarakat }\end{array}$} & \multirow[t]{2}{*}{$\begin{array}{c}\text { Kelas } \\
\text { Kesesuaian } \\
\text { Fisik Lahan }\end{array}$} & \multicolumn{3}{|c|}{$\begin{array}{c}\text { Tanggapan Masyarakat } \\
\text { tentang Keberadaan TPA } \\
\text { Sampah }\end{array}$} & \multirow[t]{2}{*}{$\begin{array}{c}\text { Kesesuaian } \\
\text { Lahan }\end{array}$} \\
\hline & & Negatif & Netral & Positif & \\
\hline Poyowa Kecil & II & & & $\sqrt{ }$ & $\begin{array}{l}\text { Cukup } \\
\text { Sesuai }\end{array}$ \\
\hline Kopandakan I & II & & $\sqrt{ }$ & & $\begin{array}{l}\text { Cukup } \\
\text { Sesuai }\end{array}$ \\
\hline Mongondow & II & & $\sqrt{ }$ & & $\begin{array}{l}\text { Cukup } \\
\text { Sesuai }\end{array}$ \\
\hline $\begin{array}{c}\text { Mongkonai } \\
\text { Barat }\end{array}$ & II & & & $\sqrt{ }$ & $\begin{array}{l}\text { Cukup } \\
\text { Sesuai }\end{array}$ \\
\hline Pemulung & II & & & $\sqrt{ }$ & $\begin{array}{l}\text { Cukup } \\
\text { Sesuai }\end{array}$ \\
\hline
\end{tabular}

\begin{tabular}{|c|c|c|c|c|}
\hline Tabel & $\begin{array}{l}\text { Keses } \\
\text { Penge } \\
\text { Mong }\end{array}$ & $\begin{array}{l}\text { ian Lahan } \\
\text { pangan } \\
\text { nai Barat }\end{array}$ & $\begin{array}{l}\text { Untuk } \\
\text { TPA }\end{array}$ & $\begin{array}{l}\text { Lokasi } \\
\text { Sampah }\end{array}$ \\
\hline \multirow[t]{2}{*}{$\begin{array}{l}\text { Responden } \\
\text { Masyarakat }\end{array}$} & \multirow{2}{*}{$\begin{array}{c}\text { Kelas } \\
\text { Kesesuaian } \\
\text { Fisik Lahan }\end{array}$} & \multicolumn{2}{|c|}{$\begin{array}{l}\text { Tanggapan Masyarakat tentang } \\
\text { Keberadaan TPA Sampah }\end{array}$} & $\begin{array}{l}\text { Kesesuaian } \\
\text { Lahan }\end{array}$ \\
\hline & & Negatif & Positif & \\
\hline $\begin{array}{l}\text { Mongkonai } \\
\text { Barat }\end{array}$ & II & $\sqrt{ }$ & & $\begin{array}{c}\text { Tidak } \\
\text { Sesuai }\end{array}$ \\
\hline
\end{tabular}

Berdasarkan Tabel 7 dan 8, dapat dijelaskan bahwa lokasi pengembangan/perluasan TPA Poyowa Kecil berada pada kategori kesesuaian lahan cukup sesuai untuk lokasi TPA sampah.Hal ini bertalian dengan kesesuaian fisik lahan II dengan kategori cukup sesuai ditunjang oleh kondisi sosial masyarakat di sekitar lokasi TPA yang cenderung menerima keberadaan lokasi TPA sampah di lingkungannya.

Sedangkan untuk lokasi pengembangan TPA sampah di wilayah Kelurahan Mongkonai Barat berada pada kategori tidak sesuai karena masyarakat di Kelurahan Mongkonai Barat tersebut cenderung menolak kehadiran TPA sampah di wilayah tersebut. Gambaran kesesuaian lahan untuk lokasi pengembangan TPA di Kota Kotamobagu seperti yang tersaji pada Gambar 7.

Berdasar hasil analisis kesesuaian lahan untuk lokasi TPA di Kota Kotamobagu sebagaimana yang tergambar pada Gambar 7, secara umum dapat dikatakan di wilayah yang diperuntukkan untuk pengembangan lokasi TPA sampah di Kota Kotamobagu yaitu Desa Poyowa Kecil dan Kelurahan Mongkonai Barat tidak ditemukan lokasi yang memenuhi kesesuaian lahan untuk lokasi TPA sampah.

Dari hasil analisis tersebut, diketahui pula bahwa faktor lingkungan sosial masyarakat yaitu penerimaan masyarakat sekitar lokasi TPA terhadap keberadaan TPA sampah yang menjadi faktor pembatas utama kesesuaian lahan untuk lokasi TPA sampah di Kota Kotamobagu.

Undang-Undang Dasar Negara Republik Indonesia Tahun 1945 pada Pasal $28 \mathrm{H}$ ayat satu menyebutkan "Setiap orang berhak hidup sejahtera lahir dan batin, bertempat tinggal dan mendapatkan lingkungan hidup yang baik dan sehat serta berhak memperoleh pelayanan kesehatan. 
Selaras dengan hal tersebut dalam konsideran "pada huruf a" undang-undang nomor 32 tahun 2009 tentang Perlindungan dan Pengelolaan Lingkungan Hidup (UUPPLH) disebutkan bahwa "Lingkungan hidup yang baik dan sehat merupakan hak asasi setiap warga negara Indonesia sebagaimana diamanatkan dalam Pasal $28 \mathrm{H}$ Undang-Undang Dasar Negara Republik Indonesia Tahun 1945".

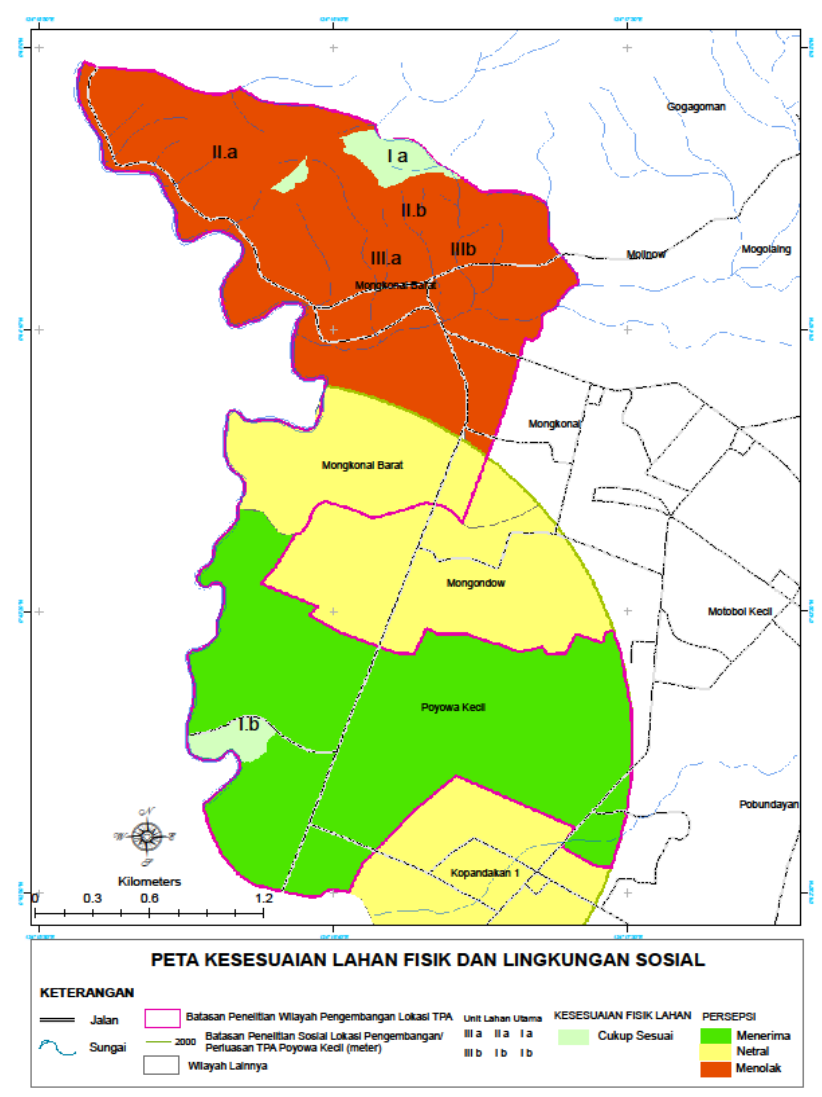

Gambar 7. Peta Potensi Kelayakan Lahan TPA Kota Kotamobagu

Pada pasal tiga Undang-Undang Perlindungan dan Pengelolaan Lingkungan Hidup disebutkan bahwa perlindungan dan pengelolaan lingkungan hidup bertujuan: (a) melindungi wilayah Negara Kesatuan Republik Indonesia dari pencemaran dan/atau kerusakan lingkungan hidup; (b) menjamin keselamatan, kesehatan, dan kehidupan manusia; (c) menjamin kelangsungan kehidupan makhluk hidup dan kelestarian ekosistem; (d) menjaga kelestarian fungsi lingkungan hidup; (e) mencapai keserasian, keselarasan, dan keseimbangan lingkungan hidup; (f) menjamin terpenuhinya keadilan generasi masa kini dan generasi masa depan; (g) menjamin pemenuhan dan perlindungan hak atas lingkungan hidup sebagai bagian dari hak asasi manusia; (h) mengendalikan pemanfaatan sumber daya alam secara bijaksana; (i) mewujudkan pembangunan berkelanjutan; dan (j) mengantisipasi isu lingkungan global.

Merujuk pada konteks perundangundangan diatas, maka perlu direkomendasikan pengkajian wilayah peruntukkan alternatif untuk pengembangan lokasi TPA di Kota Kotamobagu yang memenuhi kriteria kelayakan dan aspek penerimaan masyarakat sekitar terhadap keberadaan lokasi TPA tersebut.

\section{KESIMPULAN DAN SARAN}

\section{Kesimpulan}

1. Pada wilayah yang telah ditetapkan sebagai peruntukkan lokasi pengembangan lokasi TPA sampah terdapat satu calon lokasi pengembangan TPA sampah di Mongkonai Barat yang dikategorikan potensial layak yang berdasarkan penilaian kriteria regional pada tahapan kelayakan SNI 03-3241-1994 sebagai Standar Baku yang dipergunakan dalam penentuan lokasi TPA sampah.

2. Tanggapan masyarakat dan pemulung di sekitar lokasi pengembangan/perluasan TPA sampah di Poyowa Kecil cenderung menerima keberadaan TPA dengan memberikan penilaian netral-positif. Sedangkan untuk lokasi pengembangan TPA di Kelurahan Mongkonai Barat, 58\% dari warga masyarakat yang berada di wilayah tersebut memberikan penilaian negatif (kategori menolak) kehadiran TPA sampah di lingkungan mereka.

3. Faktor Pembatas (limiting factor) adalah keadaan yang mendekati atau melampaui batas toleransi. Faktor-faktor yang menjadi pembatas (limiting factor) tingkat kesesuaian lahan untuk lokasi TPA di Kota Kotamobagu digolongkan menjadi dua yaitu, faktor pembatas utama dan faktor 
pembatas kesesuaian fisik lahan. Faktor pembatas utama yaitu lingkungan sosial masyarakat berupa penolakan sebagian besar masyarakat terhadap keberadaan TPA sampah dan faktor pembatas fisik lahan berupa permeabilitas tanah, intensitas hujan dan kawasan pertanian produktif.

\section{Saran}

Rekomendasi alternatif kepada Stakeholder yakni Pemerintah Kota Kotamobagu antara lain:

1. Alternatif 1 , dengan pertimbangan bahwa diwilayah yang telah ditetapkan sebagai peruntukkan pengembangan lokasi TPA sampah di wilayah Kota Kotamobagu tidak terdapat lokasi yang sesuai dengan kriteria pemilihan lokasi TPA sampah, maka perlu adanya pengkajian wilayah peruntukkan alternatif untuk pengembangan lokasi TPA sampah yang baru yang memenuhi kriteria kesesuaian lahan untuk lokasi TPA sampah.

2. Alternatif 2 , dengan pertimbangan dalam rangka terselenggaranya kebijakan pemerintah Kota Kotamobagu yang telah tertuang dalam dokumen RTRW Kota Kotamobagu mengenai wilayah peruntukkan pengembangan lokasi TPA sampah serta untuk optimalisasi penggunaan peruntukkan lahan yang tersedia. Pada wilayah pengembangan lokasi TPA di Kelurahan Mongkonai Barat yang sudah memenuhi aspek kelayakan teknis yang telah ditetapkan dalam standar baku pemilihan lokasi TPA sampah yakni, SNI 03-3241-1994 Tata Cara Pemilihan Lokasi TPA dapat di dorong menjadi lokasi yang layak secara teknis bagi lingkungan dan masyarakat yang berada di wilayah tersebut, dalam hal ini pemerintah Kota Kotamobagu perlu lebih intensif untuk mensosialisasikan penyelenggaraan kegiatan tersebut baik secara individual maupun kolektif sehingga masyarakat bisa menerima kehadiran TPA sampah di wilayah tersebut.

\section{DAFTAR PUSTAKA}

Anonim. 2014. Peraturan Daerah Kota Kotamobagu Nomor 8 Tahun 2014 Tentang Rencana Tata Ruang Wilayah Kota Kotamobagu 2014-2034. Kota Kotamoabagu.

Anonim.2014. Laporan Akhir Penyusunan Masterplan Pengelolaan Persampahan Kota Kotamobagu.Badan Perencanaan Pembangunan Daerah. Kota Kotamobagu.

BPS Kota Kotamobagu. 2016. Kotamobagu Selatan Dalam Angka, 2016. Badan Pusat Statistik Kota Kotamobagu.Kota Kotamobagu.

BPS Kota Kotamobagu. 2016. Statistik Daerah Kecamatan Kotamobagu Barat, 2016. Badan Pusat Statistik Kota Kotamobagu.Kota Kotamobagu.

BSN. 1994. SNI Nomor: 03-3241-1994, Tata Cara Penentuan TPA. Badan Standarisasi Nasional. Jakarta.

Drake, M. and G. Pereira, 2002.GIS for Landfill, www.idrisi.clarku.edu.

Otieno dan Reddy. 1999. Aspect of Design of a Sanitary Landfill Site For the Durban Metropolitan Area, Proceedings Sardinia. Seventh Internasional Waste Management and Landfill Symposium.

Poedjawijatna. 1991. Tahu dan pengetahuan: Pengantar ke Ilmu dan Filsafat. Rineke Cipta, Jakarta.

Setiawan N. 2007. Penentuan Ukuran Sampel Memkai Rumus Slovin dan Tabel Krejcie-Morgan: Telaah Konsep dan Aplikasinya. Makalah disampaikan pada Diskusi Ilmiah Jurusan Sosial Ekonomi Fakultas Peternakan Unpad 22 November 2007. Fakultas Peternakan Unpad. Bandung. 
Tamod, 2008. Studi Mitigasi Sampah Kota Manado.Disertasi. Program Pascasarjana, Fakultas Pertanian. Universitas Brawijaya Malang. Malang.
Tchobanolous, G., Theisen, H. and Vigil, S. A., 1993. Integrated Solid Waste Management, Engineering Principles and Management Issues. McGraw-Hill International Editions, New York. 